\title{
Poker Sukses (Program Komputer Masuk Desa) di Lereng Gunung Sumbing
}

\author{
Ari Nurul Fatimah ${ }^{1}$ \\ Universitas Tidar, ari.nurul.fatimah@untidar.ac.id \\ Annisa Puspita Sari ${ }^{2}$ \\ Universitas Tidar, puspitaannisa6@gmail.com \\ Rizka Satria Adhi ${ }^{3}$ \\ Universitas Tidar, satriaadhi@gmail.com
}

\begin{abstract}
Abstrak
Teknologi informasi merupakan modal utama bagi setiap orang untuk dapat bersaing dalam era globalisasi. Perkembangan teknologi informasi salah satunya ditunjang dengan media komputer yang dapat digunakan oleh seluruh lapisan masyarakat. Sayangnya, masih banyak masyarakat khususnya di daerah pedesaan yang belum mampu menggunakan media komputer secara optimal seperti di lereng Gunung Sumbing, tepatnya di Desa Genito, Kecamatan Windusari, Kabupaten Magelang, Jawa Tengah. Oleh karena itu kegiatan pengabdian kepada masyarakat ini dibuat dengan tujuan untuk membekali ilmu berupa pelatihan komputer bagi anak-anak di lereng Gunung Sumbing. Komputer harus diperkenalkan kepada anak-anak sekolah agar mereka mempunyai pengetahuan dan pengalaman yang cukup untuk bisa menerapkannya dalam kehidupan sehari-hari. Kegiatan program komputer masuk desa ini dilaksanakan dengan menggunakan teknik pengumpulan informasi data primer yaitu wawancara. Tahap-tahap yang dilakukan dalam kegiatan ini yaitu survey, wawancara, sosialisasi, dan pelatihan. Dari kegiatan program komputer masuk desa yang dilaksanakan sebanyak 6 kali ini telah tercipta kegiatan pembelajaran yang menarik dan menyenangkan sebagai alternatif dalam proses pengenalan dan pembelajaran teknologi komputer dan telah tercapai target pemahaman teknologi komputer pada anak usia sekolah. Selain itu, anak-anak telah memahami tentang beberapa aplikasi computer seperti Ms. Word, Ms.Excell, Ms. Power Point, membuat surat elektronik dan alamat blog. Hal tersebut dibuktikan dengan dokumen-dokumen yang sudah dibuat oleh masing-masing peserta pelatihan pada setiap akhir pertemuan.
\end{abstract}

Kata Kunci: Pengabdian, globalisasi, teknologi, komputer

\begin{abstract}
Information technology is the main asset for people to be able to compete in the globalization era. The Development of information technology is supported by computer as a media that can be used by all levels of society. Unfortunately, there are still many people, especially in rural areas who have not be capable to use computer optimally such as on the slopes of Sumbing Mount, precisely in Genito Village, District of Windusari, Magelang Regency, Central Java. This program has purpose to share knowledge all things about computer for children on the Genito village. Computer must be introduced to children by their studies on school, so they have knowledge enough and experience to be able to apply in their daily activities. This program
\end{abstract}


are carried out using primary data collection techniques, by interviews. The stages are survey, interview, socialization, and training. From the 6 times our computer training program that has been implemented in the village, interesting and fun learning activities have been created as an alternative in the process of introducing and learning computer technology and the target of understanding computer technology has been achieved. In addition, children have understood with several computer applications such as Ms. Word, Ms. Excell, Ms. Power Point, making email, and blog addresses. This was proven by the documents that were made by each trainee at the end of each meeting.

Keywords: Dedication, globalitation, technology, computer

\section{Pendahuluan}

\section{Latar Belakang}

Teknologi informasi merupakan modal utama bagi setiap orang untuk dapat bersaing dalam era globalisasi. Perkembangan teknologi informasi salah satunya ditunjang dengan media komputer yang dapat digunakan oleh seluruh lapisan masyarakat. Dengan adanya komputer, masyarakat dapat memanfaatkan teknologi informasi secara maksimal, seperti untuk berbisnis online, untuk berkomunikasi dengan orang lain secara online, dan dapat membantu memudahkan pekerjaan seharihari. Sayangnya, masih banyak masyarakat khususnya di daerah pedesaan yang belum mampu menggunakan media komputer secara optimal seperti di lereng Gunung Sumbing, tepatnya di Desa Genito, Kecamatan Windusari, Kabupaten Magelang, Jawa Tengah. Salah satu penyebabnya ialah karena masyarakat merasa bahwa penggunaan komputer sangat rumit. Padahal potensi sumber daya alam di desa tersebut sangat melimpah. Jika sumber daya manusianya mampu mengolah sumber daya alam yang tersedia dengan optimal salah satunya melalui media komputer, tentunya hal ini dapat meningkatkan pendapatan desa dan proses pembangunan desa dapat berjalan dengan maksimal.

Pengembangan wilayah berbasis sumber daya manusia (SDM) adalah pendekatan yang harus dilaksanakan untuk membangun daerah yang kuat secara sosial dan ekonomi (Sulistyanto, 2017). (Hidayatulloh, H., 2019) menyatakan bahwa manusia yang berkualitas memiliki kecerasan emosional spiritual yang seimbang. Selain itu, sumber daya manusia yang berkualitas juga harus memiliki pengetahuan, keterampilan, dan kemampuan dala memecahkan masalah yang ada. Pengembangan sumber daya manusia merupakan salah satu fungsi MSDM utama yang tidak hanya terdiri atas pelatihan dan pengembangan, namun juga aktivitas-aktivitas perencanaan dan pengembangan karier individu, pengembangan organisasi, serta manajemen dan penilaian kinerja. Pelatihan dirancang untuk memberikan sejumlah pengetahuan dan keahlian yang diperlukan untuk pekerjaan yang dilakukan oleh seseorang dalam mendukung kinerja pribadi dan organisasi (Niati, Soelistiyono, \& Ariefiantoro, 2019). 
Dikutip dari (Diskominfo, 2013), masyarakat Desa Genito Kecamatan Windusari ingin mewujudkan desa wisata dengan mempromosikan potensi seni budaya, keindahan alam dan hasil olahan ubi jalar madu. Itulah hasil kesimpulan Wahana Komunikasi Masyarakat (WKM) yang diselenggarakan Kelompok Informasi Masyarakat (KIM) Desa Genito (8/10/2013) di Balai desa.

WKM yang menghadirkan narasumber dari Dinas Pariwisata dan Kebudayaan dari Desa Candirejo yang merupakan salah satu Wisata di Kecamatan Borobudur, serta Dinas Kominfo (Zanuar Efendi, S.IP) tersebut mengambil tema Pengembangan Desa Wisata melalui potensi Kesenian daerah dan produksi ubi jalar dimoderatori oleh Sugitno dan Yuwono sebagi penulis tersebut dikuti, disamping pengurus KIM hadir juga Pj. Kepala Desa beserta perangkat, para tukuh masyarakat dari unsur Ulama, PKK, pemuda, kelompok kesenian, kelompok tani maupun organisasi kemasyarakat lainnya. Sebelum diselenggarakan WKM, Pj. Kepala Desa telah melantik pengurus Kelompok Informasi Masyarakat (KIM) Desa Genito yang di ketuai oleh Jatmiko

Menurut Zanuar Efendi S.IP Kabid Komunikasi yang mewakili Kepala Diskominfo dalam penjelasannya mengatakan; Pembentukan (KIM) dan Wahana Komunikasi Masyarakat (WKM) yang difasiltasi Diskominfo tahun ini (2013) akan dibentuk di 5 desa pada 5 Kecamatan, sebagai kelanjutan dari program tahun-tahun sebelumnya, agar di setiap kecamatan terdapat 1 (satu) desa/Kelurahan sebagai pilot proyek keberadaan KIM. Samapai saat ini di Kab Magelang telah ada 16 KIM di 5 kelurahan dan 11 desa. Sedangkan untuk tahun ini tambah 5 desa, yaitu di Desa Sambak Kecamatan Kajoran, Desa Balekerto Kecamatan Kaliangkrik, Desa Prajeksari Kecamatan Tempuran, Desa Trasan Kecamatan Bandongan dan Desa Genito Kecamatan Windusari, jelas Zanuar.

Tujuan dibentuknya KIM, menurut Zanuar, untuk memberdayakan warga masyarakat melalui penggalian informasi dan literasi media agar potensi dan sumberdaya yang dimiliki desa bisa dimanfaatkan untuk meningkatkan kesejahteraan masyarakat. Adapun kegiatan wahana komunikasi masyarakat (WKM) dimaksudkan sebagai salah satu permodelan yang dipakai KIM dalam menggali, mencari, mengolah dan menyebarluaskan informasi dengan menghadirkan narasumber yang berkopeten sesuai dengan tema pokok bahasan, agar peserta/ warga masyarakat bisa mendapatkan solusinya.

Dari penjelasan di atas, diperlukan sebuah upaya pengabdian kepada masyarakat untuk membekali ilmu berupa pelatihan komputer bagi anak-anak di lereng Gunung Sumbing. Komputer harus diperkenalkan kepada anak-anak sekolah agar mereka mempunyai bekal pengetahuan dan pengalaman yang cukup untuk bisa menerapkannya dalam kegiatan pembelajaran. Media komputer dapat memberi pembelajaran dan pengenalan masyarakat terhadap penggunaan sarana teknologi informasi. Program komputer masuk desa juga diharapkan dapat menciptakan masyarakat yang mampu mengikuti perkembangan zaman. Sehingga nantinya masyarakat dapat memiliki semangat hidup baru dengan menghilangkan pola kehidupan pedesaan yang monoton. 


\section{Tujuan Dan Manfaat Pengabdian}

Kegiatan pengabdian kepada masyarakat ini berupa program komputer masuk desa ini dibuat dengan tujuan untuk membekali ilmu berupa pelatihan komputer bagi anak-anak di lereng Gunung Sumbing. Komputer harus diperkenalkan kepada anakanak sekolah agar mereka mempunyai pengetahuan dan pengalaman yang cukup untuk bisa menerapkannya dalam kehidupan sehari-hari. Program-program pendidikan dan latihan secara formal maupun non formal yang memberikan bekal keterampilan dan kemampuan dalam menggunakan dan memanfaatkan perangkat teknologi informasi dan komunikasi menjadi prioritas kebutuhan (Wiranto, Asmara, B., \& Tolago, A., 2015). Program komputer masuk desa diharapkan dapat menciptakan masyarakat yang mampu mengikuti perkembangan zaman sehingga nantinya masyarakat dapat memiliki semangat hidup baru dengan menghilangkan pola kehidupan pedesaan yang monoton.

Permasalahan yang hendak dipecahkan adalah bagaimana cara untuk menarik minat anak-anak agar aktif dalam kegiatan pelatihan, metode pelatihan yang diterapkan, dan bagaimana dampak atau pengaruh dari kegiatan pelatihan yang telah dilaksanakan. Manfaat dari kegiatan ini bagi mahasiswa antara lain sebagai sarana menyalurkan ide kreativitas yang dimiliki, melatih jiwa sosial dan kepekaan terhadap masyarakat sekitar, dan sebagai wujud penerapan Tri Dharma Perguruan Tinggi yaitu Pengabdian kepada Masyarakat. Sedangkan manfaat bagi peserta pelatihan dan masyarakat antara lain dapat meningkatkan pengetahuan di bidang teknologi yang nantinya dapat diterapkan dalam kehidupan sehari-hari, juga dapat menyalurkan ilmu yang diperoleh dari kegiatan ini kepada masyarakat sekitar guna meningkatkan kualitas sumber daya manusia.

\section{Kajian Pustaka}

Desa merupakan kesatuan masyarakat hokum yang memiliki batas wilayah yang mempunyai wewenang untuk mengatur dan mengurus pemerintah, dan msayarakat setempat. Salah satu kegiatan perangkat desa yaitu melakukan pengumpulan, pengolahan dan publikasi data. Profil desa dapat diakses secara online pada portal system informasi desa sehingga siapapun dapat mengakses data tersebut, adanya system portal tersebut mengharuskan para perangkat desa mampu menggunakan teknologi. Kemajuan teknologi penajian data juga harus diimbangi dengan sumber daya manusia yang memadai pula. Salah satu cara untuk memajukan sumber daya manusia yaitu dengan dibekali dengan pelatihan computer (Mufarrikoh, 2017).

(Wiranto et al., 2015) melakukan pengabdian dengan judul "Pelatihan Keterampilan Dasar Komputer dan Teknologi Informasi bagi Siswa Sekolah Dasar dan Perangkat Desa Alata Karya Kecamatan Kwandang Kabupaten Gorontalo Utara". Pelatihan ini memberikan bekal kepada siswa sekolah dan aparat desa tentang manfaat komputer dan teknologi informasi khususnya internet bagi pengembangan ilmu pengetahuan serta pemecahan masalah yang akan dihadapi dalam kehidupan kelak. Hasil dari kegiatan tersebut adalah kegiatan telah berjalan $100 \%$ dan tujuan dari 
Jurnal Pengabdian Kepada Masyarakat

pengabdian tersebut yaitu membantu meringankan pekerjaan masyarakat di desa tersebut telah tercapai.

(Sulistyanto, 2017) dalam jurnalnya yang berjudul "Pakom Pelatihan Pengoperasian Komputer Bagi Perangkat Desa di Kecamatan Gondangrejo Kabupaten Karanganyar" mengemukakan bahwa kegiatan pengabdian kepada masyarakat yang dilakukan bertujuan untuk memberikan motivasi, pengetahuan dan keterampilan/keahlian dasar dalam penguasaan teknologi komputer dan informasi guna meningkatkan skill dan kompetensi perangkat desa dalam dunia kerja melayani masyarakat. Sasaran pengabdian adalah golongan usia produktif, yaitu para perangkat desa di Desa Tuban Kecamatan Gondangrejo, Kabupaten Karanganyar, Jawa Tengah. Kegiatan pengabdian yang berbentuk pelatihan ini dilakukan dengan metode ceramah, demonstrasi, latihan, dan tanya-jawab. Namun,adanya keterbatasan jumlah alat peraga yaitu perangkat komputer dalam pelaksanaan sehingga capaian yang diharapkan dari kegiatan ini tidak dapat maksimal.

Pengelolaan adalah suatu rangkai kegiatan yang berintikan perencanaan, pengorganisasian penggerakan dan pengawasan dalam mencapai tujuan yang telah ditetapkan sebelumnya. Pengelolaan adalah serangkaian kegiatan untuk mencapai sasaran-sasaran tertentu dengan menggunakan orang-orang sebagai pelaksanaannya Pengelolaan pendidikan berasal dari kata manajemen, sedangkan istilah manajemen sama artinya dengan administrasi, dapat diartikan pengelolaan pendidikan sebagai upaya untuk menerapkan kaidah kaidah manajemen dalam bidang pendidikan. Jadi dapat disimpulkan pengelolaan merupakan suatu rangkaian kegiatan yang berintikan perencanaan, pelaksanaan dan penilaian yang dimiliki secara efektif untuk mencapai tujuan yang telah ditentukan (Berliantin, 2016).

Berdasarkan informasi dari website Pemerintah Kabupaten Magelang (Kabupaten Magelang, n.d.), Gunung Sumbing merupakan salah satu gunung yang terletak di Jawa Tengah. Di lereng Gunung Sumbing terdapat suatu kecamatan yaitu Kecamatan Windusari. Kecamatan ini merupakan wilayah dataran dan tanah perbukitan yang berada tepat di sisi barat laut Kota Magelang, Jawa Tengah. Luas wilayah Kecamatan Windusari adalah $61,65 \mathrm{~km}^{2}$ dengan ketinggian antara 663 sampai dengan $1348 \mathrm{Mdpl}$. Kecamatan Windusari berbatasan langsung dengan Kecamatan Secang di sisi Timur, Kecamatan Bandongan di sisi Selatan, Kabupaten Temanggung di sisi Utara, dan Kabupaten Wonosobo di sisi Barat. Letak Kecamatan Windusari yang berada di lereng Gunung Sumbing ini menjadikan tanah pertanian di wilayah tersebut sangat subur dan kaya akan sumber air karena ditopang oleh hutan lindung sebagai daerah resapan yang masih terjaga dengan baik.

Selain keunggulannya di sektor pertanian, keberadaan kontur perbukitan dan pegunungan menjadikan wilayah ini memiliki potensi tanaman keras (tanaman kayu) yang melimpah. Berbagai jenis tanaman kayu tumbuh dengan baik di daerah ini seperti pohon sengon, pinus, akasia, sonokeling, nangka, dan berbagai jenis bambu. Kekayaan alam yang melimpah ini menjadikan sebagian besar masyarakat di sana bekerja sebagai petani. Padahal sumber daya alam ini hendaknya diimbangi dengan kualitas sumber daya manusia yang memadai. Jika potensi ini dikembangkan dan digarap dengan baik, maka masyarakat akan mampu untuk memanfaatkan sumber daya alamnya secara maksimal. Sebagai contoh, selama ini petani yang ada hanya 
menjual hasil pertanian dan hasil perkebunan ke pengepul/tengkulak. Tetapi dengan adanya sumber daya manusia yang memahami teknologi, hasil pertanian dan perkebunan tersebut dapat dijual melalui internet. Hal ini tentunya dapat meningkatkan pendapatan masyarakat dan proses pembangunan desa dapat berjalan dengan baik.

Perkembangan teknologi yang ada belum dapat dimanfaatkan secara maksimal oleh masyarakat di lereng Gunung Sumbing. Hal tersebut disebabkan karena sebagian besar masyarakat di lereng Gunung Sumbing hanya lulusan sekolah dasar. Anak-anak di daerah tersebut hanya sebatas bersekolah dan belajar, itupun terbatas jumlahnya, sehingga mereka kurang mampu untuk bersaing di dunia kerja. Ditambah lagi, anakanak masih ragu akan kemampuan yang dimilikinya sehingga mereka takut untuk mencoba hal-hal baru seperti penggunaan komputer.

Faktor yang menjadi penyebab anak-anak ragu akan kemampuannya salah satunya adalah karena kondisi keuangan keluarga. Di lereng Gunung Sumbing, rata-rata pekerjaan orang tua adalah sebagai petani sehingga anak-anak tidak mempunyai kesempatan untuk melanjutkan sekolah ke jenjang yang lebih tinggi. Padahal di era sekarang ini, pendidikan terutama di bidang teknologi merupakan faktor utama dalam meningkatkan kualitas sumber daya manusia. Selain itu, ada beberapa hal yang dapat menghambat anak-anak dalam mempelajari teknologi salah satunya yaitu sarana dan prasarana dalam mempelajari teknologi kurang memadai. Selain itu, kurangnya motivasi dari lingkungan sekitar juga menyebabkan anak-anak merasa tidak tertarik untuk mempelajari teknologi informasi.

Oleh karena itu, program pengabdian kepada masyarakat ini diharapkan dapat meningkatkan kualotas sumbr daya manusia di Desa Genito terhadap kemajuan teknologi.

\section{Metode}

\section{Tahapan Metode}

Metode pelaksanaan kegiatan dalam pengabdian kepada masyarakat bertujuan untuk mencari solusi dari permasalahan yang dialami oleh perangkat desa (Niati et al., 2019). Kegiatan program kreativitas mahasiswa (PKM) pengabdian kepada masyarakat ini dilaksanakan dengan menggunakan teknik pengumpulan informasi data primer yaitu wawancara. Tahap-tahap yang dilakukan dalam kegiatan pengabdian ini yaitu survey, wawancara, sosialisasi, dan pelatihan. Survey dilakukan dengan cara mengunjungi langsung desa Genito dan melakukan pengamatan mengenai situasi dan kondisi masyarakat desa tersebut terutama yang berhubungan dengan teknologi. Kegiatan survei dilaksanakan pada bulan Oktober 2018.

Tahap selanjutnya yaitu wawancara. Pada tahap wawancara, narasumber yang diwawancarai adalah masyarakat Desa Genito khususnya anak-anak usia sekolah untuk mengetahui sejauh mana pengetahuan anak-anak tentang teknologi dan kemampuan anak-anak dalam mengoperasikan komputer, serta ketersediaan komputer sebagai media pembelajaran. Berbagai permasalahan dalam pengoperasian 
komputer juga dijadikan sebagai bahan wawancara. Tahap wawancara dilaksanakan pada Bulan November 2018 yang dilakukan di wilayah Desa Genito. Dari tahap wawancara dapat diketahui bahwa pengetahuan anak-anak mengenai teknologi komputer sangat minim. Bukan disebabkan oleh ketidakmauan untuk belajar tetapi disebabkan oleh faktor lingkungan dimana tidak semua anak memiliki komputer atau laptop dan tidak ada orang yang melatih keterampilan mereka dalam mengoperasikan komputer.

Tahap berikutnya adalah sosialisasi mengenai pentingnya pengetahuan tentang teknologi dan bagaimana pelatihan program komputer dijalankan. Sosialisasi dilakukan satu minggu sebelum pelatihan komputer dilaksanakan. Dari sosialisasi ini diharapkan dapat meningkatkan minat anak-anak untuk mengikuti kegiatan pelatihan. Tahap terakhir yaitu pelatihan komputer yang dilaksanakan selama 2 bulan dengan 6 kali pertemuan. Setiap pertemuan dimulai pada pukul 09.00 sampai dengan pukul 11.15 WIB di Balai Desa Genito. Metode yang digunakan untuk menggugah semangat para peserta adalah metode pembelajaran yang menarik dan menyenangkan dengan mengajak peserta untuk berinteraksi dengan warna-warna, gambar, dan sesuatu yang instan, serta mengadakan kuis berhadiah. Adapun materi yang disampaikan selama 6 kali pertemuan adalah pengenalan komputer, microsoft word, microsoft excel, microsoft power point, email dan blog.

Dalam kegiatan pelatihan, peralatan atau perlengkapan yang diperlukan diantaranya yaitu meja dan kursi, 6 buah laptop, 1 buah proyektor, penggandaan materi, bolpoint, spidol, kertas hvs, printer, hadiah, dan stop kontak.

Pelaksanaan kegiatan pelatihan komputer menggunakan berbagai alat dan perlengkapan diantaranya meja dan kursi, 6 buah laptop, 1 buah proyektor, penggandaan materi, bolpoint, spidol, kertas hvs, printer, stop kontak, dan hadiah. Berbagai fasilitas yang disediakan digunakan untuk menunjang proses pelatihan dan proses pembelajaran yang efektif.

Berikut materi yang telah disampaikan dalam enam kali pertemuan:

Tabel.1 Materi enam kali pertemuan

\begin{tabular}{|c|c|c|}
\hline No & Waktu & Materi \\
\hline 1 & $\begin{array}{l}\text { Minggu ke-1 } \\
\text { (19 Mei 2019) }\end{array}$ & $\begin{array}{l}\text { Pengenalan program komputer dan fungsi } \\
\text { keyboard, seperti cara menyalakan dan } \\
\text { mematikan komputer, fungsi dari control } \\
\text { panel, fungai tombol pada keyboard, fungsi } \\
\text { tombol pada mouse, dan sebagainya. }\end{array}$ \\
\hline 2 & $\begin{array}{l}\text { Minggu ke-2 } \\
\text { (25 Mei 2019) }\end{array}$ & $\begin{array}{l}\text { Aplikasi pengolah kata (microsoft word), } \\
\text { seperti membuat dokumen baru, penjelasan } \\
\text { fungsi menu bar, belajar mengetik, dan } \\
\text { sebagainya. }\end{array}$ \\
\hline
\end{tabular}


Jurnal Pengabdian Kepada Masyarakat

\begin{tabular}{|c|c|c|}
\hline 3 & $\begin{array}{l}\text { Minggu ke-3 } \\
\text { (26 Mei 2019) }\end{array}$ & $\begin{array}{l}\text { Akses internet, seperti browsing, mengunduh } \\
\text { gambar, menyalin teks dari internet, serta } \\
\text { mengedit ke microsoft word. }\end{array}$ \\
\hline 4 & $\begin{array}{l}\text { Minggu ke-4 } \\
\text { (16 Juni 2019) }\end{array}$ & $\begin{array}{l}\text { Aplikasi pengolah angka (microsoft excel), } \\
\text { seperti membuat dokumen baru, } \\
\text { penggunaan rumus dan fungsi, dan } \\
\text { sebagainya. }\end{array}$ \\
\hline 5 & $\begin{array}{l}\text { Minggu ke-5 } \\
\text { (23 Juni 2019) }\end{array}$ & $\begin{array}{l}\text { Aplikasi pengolah presentasi (microsoft power } \\
\text { point), seperti membuat slide, membuat } \\
\text { animasi, mengganti desain (tema), dan } \\
\text { sebagainya. }\end{array}$ \\
\hline 6 & $\begin{array}{l}\text { Minggu ke-6 } \\
\text { (30 Juni 2019) }\end{array}$ & $\begin{array}{l}\text { Email dan blog, seperti cara membuat email, } \\
\text { login ke email, fungsi dari email, fasilitas- } \\
\text { fasilitas dalam email, cara mengirim email, } \\
\text { menyimpan dokumen ke google drive, } \\
\text { membuat blog, dan sebagainya. Dilanjutkan } \\
\text { dengan penutupan kegiatan pelatihan. }\end{array}$ \\
\hline
\end{tabular}

\section{Hasil dan Pembahasan}

Program komputer masuk desa telah dilaksanakan sebanyak 6 kali, artinya kegiatan ini telah berjalan 100\%. Dari 6 kali kegiatan ini dihasilkan sebagai berikut:

1. Tercipta kegiatan pembelajaran yang menarik dan menyenangkan sebagai alternatif dalam proses pengenalan dan pembelajaran teknologi komputer. Kegiatan pembelajaran yang menarik menjadikan anak-anak lebih termotivasi dalam mengikuti kegiatan pelatihan. Salah satu upaya untuk menghidupkan setiap pertemuan adalah dengan menarik perhatian anak-anak dengan cara memberikan hadiah di setiap penghujung acara. Hal tersebut memberikan semangat anak-anak untuk memperhatikan dan aktif dalam setiap pembelajaran. Tetapi selain keaktifan dan kuis, tim juga mempertimbangkan hal lain agar setiap anak mendapat hadiah sehingga anak-anak pernah merasakan mendapat hadiah dan berani berbicara atau menjawab pertanyaan saat pembelajaran.

2. Tercapainya target pemahaman teknologi komputer pada anak usia sekolah di lereng Gunung Sumbing. Anak-anak mulai dapat mengoperasikan komputer dengan baik. Hal tersebut dibuktikan pada saat pelatihan, mereka sering mencoba untuk mengoperasikan komputer secara mandiri, dan sesekali mereka mengajukan pertanyaan mengenai komputer. Tim pelaksana telah mempersiapkan materi pada setiap pertemuan dan memberi tahu anak-anak pada pertemuan sebelumnya, sehingga anak-anak telah mengetahui dan mempersiapkan hal yang baru untuk pertemuan selanjutnya. Saat penyampaian materi, sesekali tim bertanya kepada anakanak apakah mereka sudah paham atau belum sehingga ketika anak-anak merasa kurang paham, tim akan menjelaskan ulang materi yang disampaikan. 
Jurnal Pengabdian Kepada Masyarakat

Berikut adalah gambar dalam pelaksanaan pengabdian masyarakat.

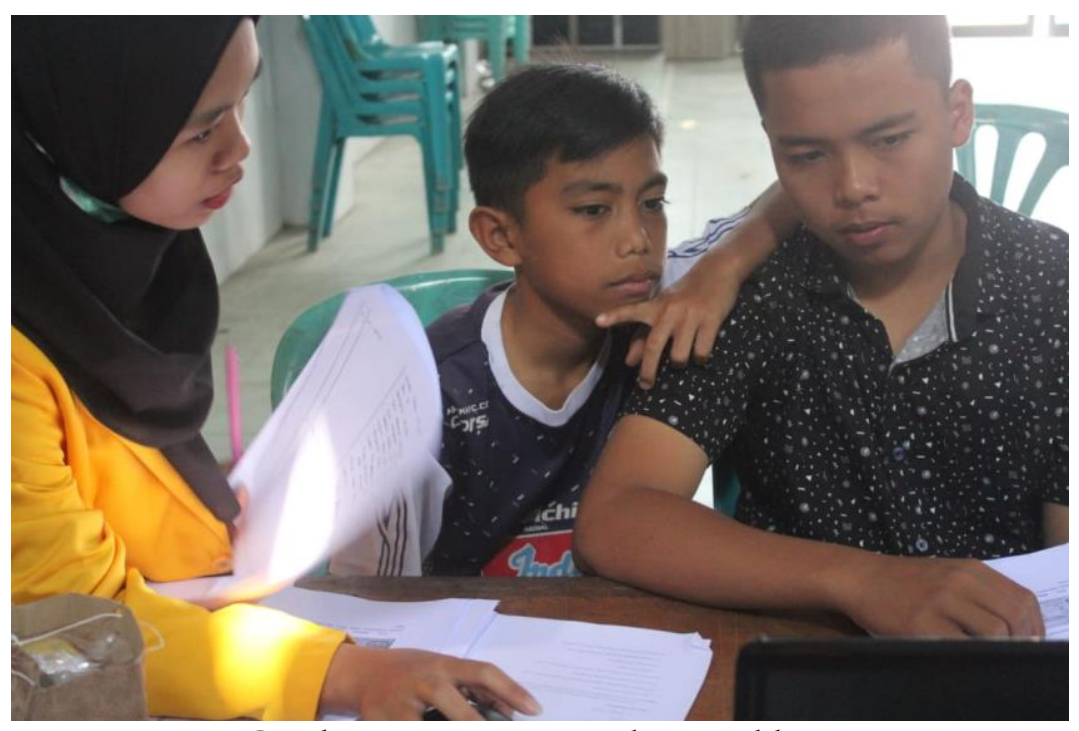

Gambar.1 Proses mempelajari aplikasi

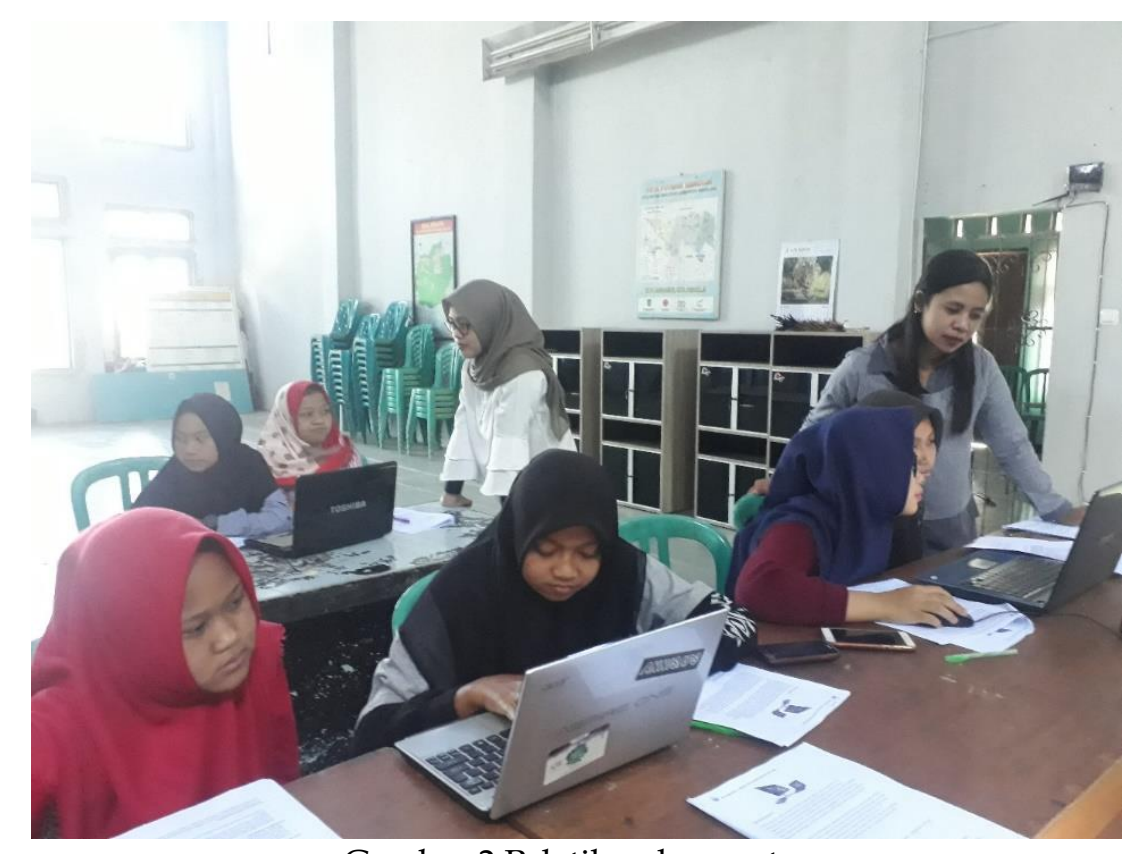

Gambar.2 Pelatihan komputer 


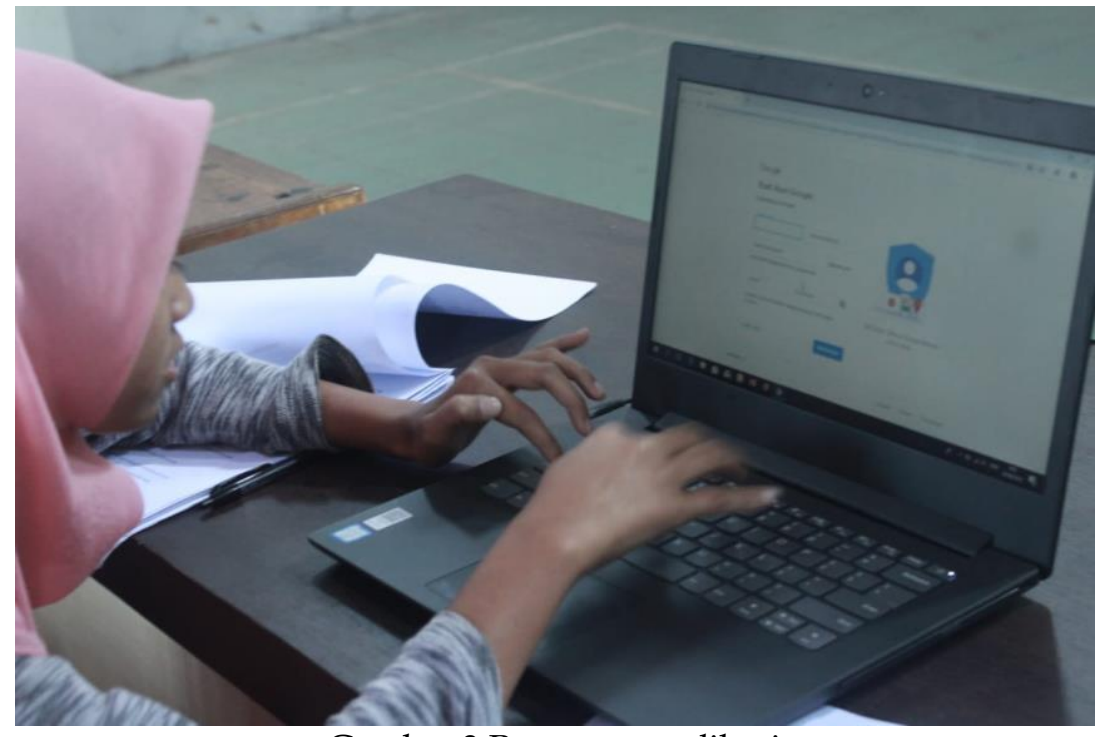

Gambar.3 Penerapan aplikasi

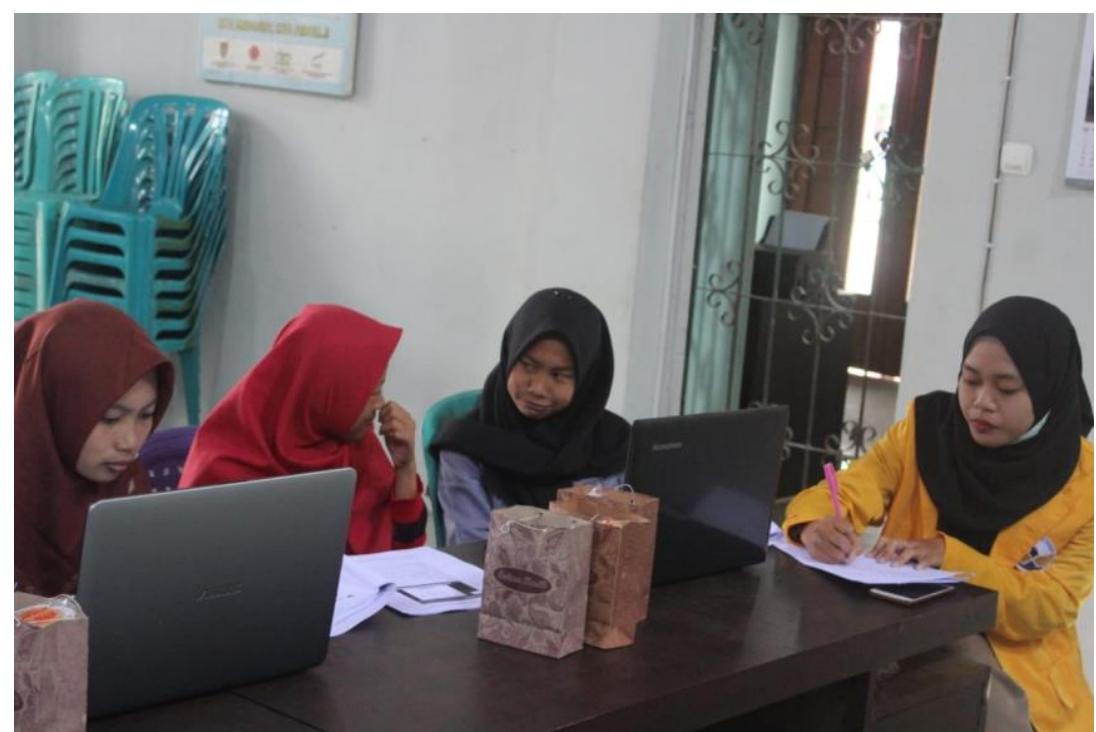

Gambar.4 Sesi tanya jawab

Program komputer masuk desa ini memberikan manfaat bagi masyarakat Desa Genito khususnya peserta pelatihan, antara lain: Memberikan manfaat bagi masyarakat khususnya peserta pelatihan, yaitu peserta pelatihan menjadi lebih terampil dalam mengoperasikan komputer. Hal tersebut dapat dibuktikan dari dokumen-dokumen yang telah mereka buat melalui aplikasi-aplikasi yang ada di kompter. Tidak hanya dokumen, surat elektronik dan blog pun sudah dibuat oleh mereka. Kemudian dengan meningkatnya keterampilan yang dimiliki oleh peserta pelatihan, maka kualitas sumber daya manusia di Desa Genito mengalami peningkatan. Pelatihan tersebut diharapkan dapat menjadi bekal masa depannya nanti. Setelah pelaksanaan pelatihan selesai, peserta diharapkan dapat meyalurkan ilmunya kepada anak-anak dan masyarakat sekitar agar ilmu yang telah disampaikan dapat dimanfaatkan untuk kepentingan seluruh masyarakat di Desa Genito. Pelatihan 
komputer masuk desa ini diharapkan bermanfaat untuk proses dalam pembuatan dokumen dan meningkatkan sumber daya manusia di Desa Genito. Menyiapkan peserta pelatihan agar dapat menyesuaikan diri dengan kemajuan zaman yang serba terkomputerisasi.

Dengan adanya kegiatan program komputer masuk desa ini, terdapat beberapa aspek yang berpengaruh yaitu:

\section{Aspek Pendidikan}

Program PKM dilakukan untuk memberikan pelatihan pada para peserta yang umumnya masih duduk dibangku SMP. Peserta diharapkan dapat mempersiapkan diri dalam menghadapi dunia modern serta dapat mengimplementasikan ilmunya kepada masyarakat dan lingkungan sekitar.

\section{Aspek Ekonomi}

Ketika para peserta sudah dapat mengimplementasikan ilmu-ilmu yang telah didapat, hal ini dapat menjadi jembatan dengan memajukan sektor perekonomian di Desa Genito. Hal tersebut dapat dilihat dari sisi pariwisata, pertanian ataupun perindustrian yang diharapkan nantinya mampu memaksimalkan potensi pemasaran dan meningkatkan pendapatan dari Desa Genito bahkan dapat menjadi peluang terbukanya lapangan pekerjaan bagi masyarakat desa tersebut.

\section{Simpulan dan Rekomendasi}

Wilayah yang subur dan kaya akan sumber daya alam hendaknya diimbangi dengan kualitas sumber daya manusia yang mumpuni. Jika kualitas sumber daya manusianya dikembangkan dengan baik maka sumber daya alam yang tersedia dapat diolah dengan maksimal. Salah satu upaya untuk meningkatkan kualitas sumber daya manusia adalah dengan penerapan teknologi.

Kegiatan Program Kreativitas Mahasiswa (PKM) ini dibuat dengan tujuan untuk membantu masyarakat Desa Genito agar dapat mengoperasikan komputer dan memaksimalkan kemampuan yang ada. Metode pelaksanaan yang dilakukan antara lain tahap survey, wawancara, sosialisasi, dan pelatihan. Kegiatan dilaksanakan sebanyak 6 kali pertemuan, dan hasil dari kegiatan tersebut yaitu tercipta kegiatan pembelajaran yang menarik dan menyenangkan. Kegiatan pembelajaran yang menarik menjadikan anak-anak lebih termotivasi dalam mengikuti kegiatan pelatihan, tercapainya target pemahaman teknologi komputer pada peserta pelatihan.

Anak-anak mulai dapat mengoperasikan komputer dengan baik. Hal tersebut dibuktikan pada saat pelatihan, mereka sering mencoba untuk mengoperasikan komputer secara mandiri dan sesekali mengajukan pertanyaan mengenai komputer. Kegiatan program komputer masuk desa ini perlu dilaksanakan kembali khususnya di daerah yang masih tertinggal karena komputer merupakan salah satu teknologi yang penting dan berguna untuk membantu pekerjaan manusia sehari-hari. Jika akan dilaksanakan pelatihan komputer semacam ini, sebaiknya memilih daerah atau masyarakat yang tepat, sehingga sasaran dan target kegiatan dapat tercapai dengan baik. 
Jurnal Pengabdian Kepada Masyarakat

\section{Daftar Pustaka}

Berliantin, C. (2016). Pengelolaan Program Kursus Komputer Pada Bidang Keahlian Di Lkp Alfabank Semarang.

Diskominfo. (2013). No Title. Retrieved from diskominfo.magelangkab.go.id

Hidayatulloh, H., N. (2019). Implementasi Program Pelatihan Komputer bagi Warga Belajar Paket C di PKBM Bina Terampil Mandiri Kertawangi. COMM-EDU, 2. Retrieved from https://journal.ikipsiliwangi.ac.id/index.php/comm-edu/ article/view/2450

Kabupaten Magelang, P. (n.d.). No Title. Retrieved from www.magelangkab.go.id.

Mufarrikoh, Z. (2017). Analisis Kemampuan Perangkat Desa Murtajih dalam Pengoperasian Komputer, 1(3), 221-224.

Niati, A., Soelistiyono, A., \& Ariefiantoro, T. (2019). Pengembangan Kemampuan Sumber Daya Manusia melalui Pelatihan Komputer Microsoft Office Excel untuk Meningkatkan Kinerja Perangkat Desa Mranggen. E-Dimas: Jurnal Pengabdian Kepada Masyarakat, 10(1), 105. https://doi.org/10.26877/e-dimas.v10i1.3557

Sulistyanto, H. (2017). Pakom Pelatihan Komputer bagi Perangkat Desa di Kecamatan Gondangrejo Kabupaten Karanganyar. WARTA LPM, 20, 111-114. Retrieved from http://journals.ums.ac.id/index.php/warta/article/view/4757/3487

Wiranto, I., Asmara, B., A., \& Tolago, A., I. (2015). Laporan akhir kks pengabdian lembaga pengabdian masyarakat universitas negeri gorontalo tahun 2015. 